\title{
Comparison of Two Morphometric Linear Methods to Measure the Alveolar Bone Loss Induced by Experimental Periodontal Disease in Rats
}

\author{
Ratlarda Oluşturulan Deneysel Periodontitis Modelinde Alveoler \\ Kemik Kaybının Ölçümünde iki Morfometrik Doğrusal Yöntemin \\ Karşılaştırılması
}

(D) Mehtap Bilgin Çetin, (DD Yasemin Sezgin

Başkent University Faculty of Dentistry, Department of Periodontology, Ankara, Turkey

Keywords

Alveolar bone loss, experimental periodontitis, morphometric measurements, rats

Anahtar Kelimeler

Alveoler kemik kaybı, deneysel periodontitis, morfometrik ölçüm, sıçan

Received/Geliş Tarihi : 09.06.2020

Accepted/Kabul Tarihi : 31.08.2020

doi:10.4274/meandros.galenos.2020.48615

Address for Correspondence/Yazışma Adresi: Mehtap Bilgin Çetin MD,

Başkent University Faculty of Dentistry,

Department of Periodontology, Ankara, Turkey

Phone : +90 5056344229

E-mail : mehtapblgn@yahoo.com

ORCID ID: orcid.org/0000-0003-3164-6886

(C) Meandros Medical and Dental Journal, Published by Galenos Publishing House.

This is article distributed under the terms of the

Creative Commons Attribution NonCommercial 4.0

International Licence (CC BY-NC 4.0).

\section{Abstract}

Objective: The aim of this study was to compare the direct and indirect linear morphometric measurements for the evaluation of alveolar bone loss after experimentally induced periodontitis in rats.

Materials and Methods: Right mandibles of 30 Sprague Dawley rats were collected from a previous study which induced periodontitis using ligature model. In direct measurement group, the distance between cementoenamel junction and alveolar bone crest was evaluated by digital caliper and periodontal probe with a dental loop, whereas indirect group measurement was performed by an image analysis program on digital photographs.

Results: The difference between groups was determined using Mann-Whitney U test. Average alveolar bone loss was $1.08 \pm 0.22 \mathrm{~mm}$ in direct measurement group and $1.19 \pm 0.33 \mathrm{~mm}$ inindirect measurement group. The variation between direct and in direct groups was not statistically significant ( $p>0.05)$.

Conclusion: Based on the present result, it can be concluded that direct morphometric analysis might be an essential alternative to indirect morphometric evaluations to measure alveolar bone loss after experimentally induced periodontitis in rats.

Öz

Amaç: Bu çalışmanın amacı, alveoler kemik kaybını değerlendirmek için direkt (alveoler kemik üzerinde dijital bir kumpas ve dental loop ile gerçekleştirilen) ve indirekt (dijital fotoğraflarda özel bir yazılım programı aracılığıyla gerçekleştirilen) doğrusal morfometrik ölçümleri karşılaştırmaktır.

Gereç ve Yöntemler: Çalışmamızda kullanılan 30 adet Sprague Dawley sıçan alt çenesi ligatür modeli ile deneysel periodontitis oluşturulmuş önceki bir çalışmadan elde edilmiştir. Mine-sement sınırından alveoler kemik kretine olan mesafe, direkt ölçüm grubunda dijital kumpas ve periodontal sond kullanılarak dental loop ile ölçülürken; indirekt ölçüm grubunda ise özel bir görüntü analiz programı ile dijital fotoğraflar üzerinde gerçekleştirilmiştir. 
Bulgular: Mann-Whitney U testi, gruplar arası değerlendirme için kullanılmıştır. Alveoler kemik kaybı direkt ölçüm grubunda

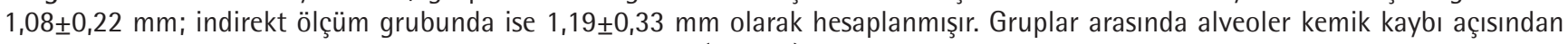
istatistiksel bakımdan anlamlı bir değişim belirlenmemiştir $(p>0,05)$.

Sonuç: Bu sonuca dayanarak, direkt morfometrik analiz kullanımının, sıçanlarda deneysel periodontitis oluşumundan sonra meydana gelen alveoler kemik kaybını ölçmek için indirekt morfometrik değerlendirmelere alternatif olabileceğini söyleyebiliriz.

\section{Introduction}

Periodontitis is a chronic inflammatory disease which yields damages in the supporting tissues of the teeth such as periodontal ligament, alveolar bone and gingiva. Parameters including host response, genetic and environmental factors play critical roles in the development of periodontal diseases and their progression (1). Since it is not always possible to detect these parameters in humans due to confounding factors or ethical problems, researchers have turned to experimental studies in various animal models (2).

Animal such as mice, hamsters, rats, minks, dogs, cats, wolves, foxes, sheep and horses, along with different non-human primates are mainly used for laboratory experiments. Primates are considered to be the best animal model since they are close relatives of humans, however these animals are not preferred in large scale studies due to their high costs. Rats are frequently preferred in experimental periodontitis studies due to multiple advantages including being cheap, easy to obtain and easy to use $(3,4)$.

There are several methods of inducing periodontal disease in rats, such as localized injection of inactive bacteria or pathogen component, oral gavage and ligature model (5). The most commonly utilized method to induce experimental periodontitis is the ligature model which causes plaque accumulation and colonization through placing ligatures on the cervical portion of the second molar teeth of maxillary or first molar teeth of mandibular (6-11).

After the induction of periodontitis, quantifying the destruction is critical to figure out the effect of the factors investigated in the disease development. For this reason, multiple measurement methods such as morphometric, histological and microcomputed tomography (micro-CT) have been utilized to detect the loss of bone in experimentally triggered periodontitis models (12). In a previous research conducted by Li and Amar (13), no difference was detected in the accuracy of parameters including morphometric, histometric and micro-CT analysis. Similarly Fernandes et al. (7) evaluated the procedures with morphometric and histometric bases and represented that these techniques extensively detected alveolar bone loss in rats.

Morphometrical evaluation usually consists of linear and area measurements of alveolar bone loss. Morphometric evaluation is performed by a special software program using digital photographs (indirect). Another technique to linearly measure the alveolar bone loss is direct visual method which refers to the measurement made by a dental loop and digital caliper over the alveolar bone. By this way, the necessity of using of a software program and digital camera is eliminated. Therefore, this study was conducted to compare direct and indirect linear measurements to assess the alveolar bone loss. The tested hypothesis declare that direct linear measurement would be similar to indirect linear measurement to evaluate the alveolar bone loss following experimentally triggered periodontitis in rats by ligatures.

\section{Materials and Methods}

\section{Animals}

Thirty right mandibles were collected from a previous study in which periodontitis was induced in 63 male Sprague Dawley rats weighing average of 300-400 grams. Department of Medical Science Application and Research Centre of Başkent University has provided the rats. This research has been approved by Başkent University Institutional Review Board (decision no: 16/29, date: 11.04.2016) and supported by Başkent University Research Fund. During the experimental period, the housing rooms of the rats were around $22 \pm 1{ }^{\circ} \mathrm{C}$ temperature, along with 12 hours of light/dark cycle. The rats were fed ad libitum using commercially available rat chow and water. All research techniques were authorized by Governmental Animal Protection Committee and the Animal Ethics Committee of Başkent University. 
The research was carried out in agreement with the Helsinki Declaration.

\section{Periodontitis Induction and Specimen Preparation}

General anesthesia was performed intraperitoneally using solution containing ketamine and $2 \%$ Xylazine in $50 \mathrm{mg} / \mathrm{kg}$ and $8 \mathrm{mg} /$ kg concentrations, respectively. Following general anesthesia, each animal was located on the operating table by leaving the rat's mouth open in order to reach to the mandibular first molar teeth. Next, 3.0 silk ligatures (Doğsan, Trabzon, Turkey) were located by the mandibular first molars in order to trigger periodontitis. Thirty days later, the rats were decapitated. The mandibles and maxillas were collected. The fixation process of the specimens were performed using $10 \%$ formalin solution after the mandibles were defleshed using 9\% sodium hypochlorite solution for 5 consecutive hours. Following the removal of soft tissue, the staining of the specimens were carried out using $1 \%$ methylene blue solution (Sigma-Aldrich, Saint Louis, MO, USA) for 1 minute to demarcate the cementoenamel junction (CEJ). The mandibles were placed in alginate impression to keep their occlusal surface parallel to the ground and a millimeter ruler was attached to the mandible as reference. Photographic images were obtained using a digital camera with Canon EOS 600D brand (Canon, Tokyo, Japan) coupled to a tripod in order to stabilize the camera in a parallel position to the floor at the minimal focal distance. A blinded and calibrated examiner has detected the alveolar bone loss through direct and indirect morphometric analysis.

\section{Indirect Morphometric Analysis of Alveolar Bone Loss}

Indirect morphometric analysis was conducted through evaluating standard digital photographs. The distance between CEJ and the alveolar bone crest $(A B C)$ was determined at three equidistant sites for three times, utilizing an image processing software (Image J 1.34 s; US National Institutes of Health, Bethesda, MD, USA). To confirm the conversions of measurements, all samples were photographed along with millimeter ruler. The pixel measurements were turned into millimeter using the labeling on the millimeter ruler. An average value for each analysis was then obtained from each mandible. Figure 1 represents the samples and analysis performed on the buccal aspect.

Direct Morphometric Analysis of Alveolar Bone Loss (Direct Visual Evaluation)

Bone loss measurements were performed using a dental loop (Heine, Herrsching, Germany) with a magnification of $\times 2.5$, periodontal probe and a digital caliper. As in indirect analysis, alveolar bone loss measurement was performed at three sites. To measure the linear interval between CEJ and the deepest part of the defect, periodontal probe was placed at the base of the bone crest parallel to the vertical axis of the root surface. The point at the CEJ was marked using a tiny endodontic rubber ring. The distance from the periodontal probe tip to the rubber ring was recorded by digital caliper.

\section{Statistical Analysis}

For direct and indirect measurement groups, linear alveolar bone loss was determined as mean \pm standard deviation. The obtained findings were investigated for normality of distribution using Shapiro-Wilk test. Since the data did not represent a normal distribution, we conducted Mann-Whitney $U$ test for the detection of the variation between two groups. A p-value greater than 0.05 was designated as statistically insignificant in the tests performed.

\section{Results}

Results obtained from the direct and indirect linear morphometric assessments of average bone loss of alveolus are demonstrated in Figure 2. Average linear

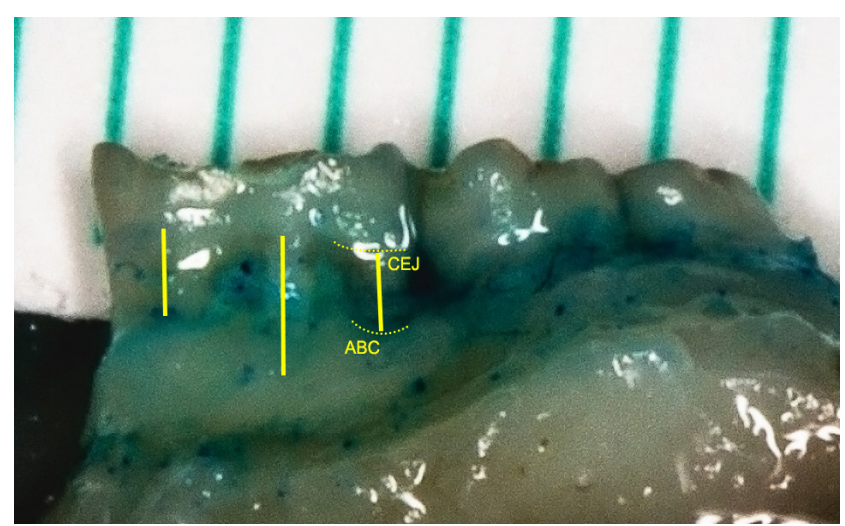

Figure 1. Image of alveolar bone loss evaluation through indirect linear morphometric measurement. The distance between cemento-enamel junction and the alveolar bone crest was determined at three equidistant sites

ABC: Alveolar bone crest, CEJ: Cementoenamel junction 
analysis of bone loss are represented in millimeters. Mean alveolar bone loss has been found $1.08 \pm 0.22$ $\mathrm{mm}$ indirect measurement group, whereas it was $1.19 \pm 0.33 \mathrm{~mm}$ in indirect measurement group. The variation between direct and indirect groups was found statistically insignificant $(p=0.34)$.

\section{Discussion}

The goal of this current research was to assess two different linear morphometric methods for alveolar bone loss measurements after placing ligatures in order to experimentally induce periodontitis in rats. Direct (performed by a dental loop, periodontal probe and digital caliper over the alveolar bone) and indirect (performed by a special software program on digital photographs) linear morphometric measurements were performed on defleshed mandibles. It was observed that both direct and indirect linear morphometric methods could be used, since no statistically significance was obtained between these groups in terms of bone loss.

Several methods were used to induce periodontal disease in rats. In parallel with the current study, using cotton ligatures has been reported in multiple researches including the cervical part of the second molar of maxillary and first molar of mandibular. Since the cheek and tongue limits working by the mandible, some studies concentrated on inducing experimental periodontitis in maxilla (14-18). However, since periodontitis can be observed in both jaws, there are many studies using mandibles in the literature (19-24).

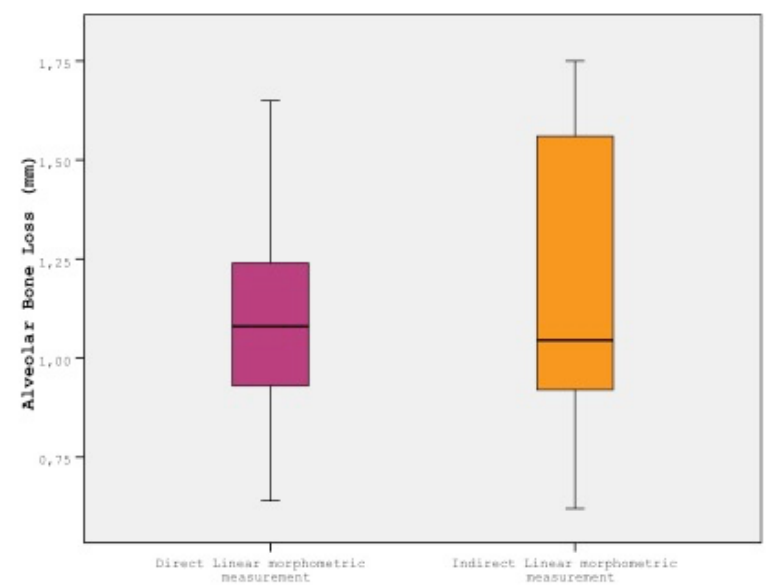

Figure 2. Linear direct and indirect morphometric measurements
Consistent with previous researches, periodontitis was triggered in the mandibular first molar teeth in the present study.

It was confirmed that the bone loss might be detected on short-time period after the placement of cotton ligature and the experimental procedure might differ between 7 to 60 days $(10,25)$. Similar to the several previous studies, ligatures remained for 30 days in this present study $(7,11,26,27)$.

Animal models have been widely used to detect the effect of risk factors which might significantly affect the initiation or development of a periodontal disease $(17,18,22,28-34)$. Previous animal studies widely focused on the biological plausibility of the events and a limited number of them concentrated on methodological aspects which might alter the findings. For instance, Park et al. (28) suggested utilization of micro-computed tomography due to the compact agreement between examiners, increased reliability and high reproducibility. Li and Amar (13) have reported accuracy in micro-computed tomography, along with the histometric and morphometric measurements for the assessment of alveolar bone loss.

Morphometric measurements were achieved by two different methods and the comparison of linear and area methods were obtained in previous studies. Kuhr et al. (25) conducted a study to compare these two morphometric techniques to assess the loss of bone in the defleshed jaw. It was found that when a longer period of time was provided, these two methods as well did not represent a correlation. The authors declared that the linear method is suggested to be utilized when there is a minor variation in bone loss among the experimental groups. In contrast, Liberman et al. (35) found an almost perfect association between the linear and area evaluations. Similarly, de Souza et al. (36) compared linear and area techniques, yet the findings did not represent statistical significance. It was concluded that both methods were applicable for detecting alveolar bone loss.

Linear method has been extensively used for morphometric measurement of alveolar bone (31,32,37-39). Previous studies performed linear morphometric measurements to evaluate alveolar bone loss by taking standardized pictures from the specimens and using image analysis computer 
software thereafter. This analysis was compared previously with histometric and micro-computed tomographic analyses in order to quantify alveolar bone loss and it was concluded that both are adequate enough to evaluate bone loss in rats $(7,13)$. Although morphometric linear technique performed on digital photographs is accurate in detecting bone loss and reproducible (13), the necessity of a digital camera and an image analysis software is among the disadvantages of this technique. There is only one study in the literature that compared direct and indirect methods of the distance from the junction of cemento-enamel to the bone crest of alveolus measurements. Bakır and Ay (40) reported no significant difference in measurements in two groups. Due to the scarce of the literature in this field, current study compared direct and indirect morphometric analysis to measure alveolar bone loss in rats. According to findings of the current research, direct linear morphometric measurement might be considered as an easier method without a need for a digital camera or image analysis software to address the bone loss following experimentally triggered periodontitis in rats.

\section{Conclusion}

The current research includes the use of direct morphometric analysis which might be a substitute of indirect morphometric analysis to measure alveolar bone loss in rats after the induction of experimental periodontitis. Measuring without a digital camera or image analysis software is easier and requires less time, especially when the sole purpose of research is to address bone loss. Additional research is demanded to validate the findings of present study.

\section{Ethics}

Ethics Committee Approval: This research has been approved by Başkent University Institutional Review Board (decision no: 16/29, date: 11.04.2016).

Informed Consent: This study is an animal experiment.

Peer-review: Externally peer-reviewed.

\section{Authorship Contributions}

Concept: M.B., Y.S., Design: M.B.Ç., Y.S., Supervision: M.B.C.., Y.S., Fundings: M.B.Ç., Y.S., Materials: M.B.Ç., Y.S., Data Collection or Processing: M.B.Ç., Y.S., Analysis or Interpretation: M.B.Ç., Y.S.,
Literature Search: M.B.Ç., Y.S., Writing: M.B.C.., Y.S., Critical Review: M.B.Ç., Y.S.

Conflict of Interest: No conflict of interest was declared by the authors.

Financial Disclosure: This research has been supported by Başkent University Research Fund.

\section{References}

1. Page RC, Offenbacher S, Schroeder HE, Seymour GJ, Kornman KS. Advances in the pathogenesis of periodontitis: summary of developments, clinical implications and future directions. Periodontol 2000 1997; 14: 216-48.

2. Klausen B. Microbiological and immunological aspects of experimental periodontal disease in rats: a review article. J Periodontol 1991; 62: 59-73.

3. Jasmin C, Jasmin JR, Brocheriou C. [Animal models in oro-dental research]. Actual Odontostomatol (Paris) 1984; 38: 723-43.

4. McArthur WP, Magnusson I, Marks RG, Clark WB. Modulation of colonization by black-pigmented Bacteroides species in squirrel monkeys by immunization with Bacteroides gingivalis. Infect Immun 1989; 57: 2313-7.

5. Struillou X, Boutigny $H$, Soueidan A, Layrolle P. Experimental animal models in periodontology: a review. Open Dent J 2010; 4: 37-47.

6. Tantiana RD, Setijanto D, Kinant A, Firman A. The ability of electrolyzed reduced water to act as an antioxidant and antiinflammatory agent in chronic periodontitis wistar rats (rattus novergicus). Kafkas Univ Vet Fak Derg 2019; 25: 539-44.

7. Fernandes MI, Gaio EJ, Oppermann RV, Rados PV, Rosing CK. Comparison of histometric and morphometric analyses of bone height in ligature-induced periodontitis in rats. Braz Oral Res 2007; 21: 216-21.

8. Anbinder AL, Prado M de A, Spalding M, Balducci I, Carvalho YR, da Rocha RF. Estrogen deficiency and periodontal condition in rats: a radiographic and macroscopic study. Braz Dent J 2006; 17: 201-7.

9. Bain JL, Lester SR, Henry WD, Bishop CM, Turnage AA, Naftel $J P$, et al. Comparative gender differences in local and systemic concentrations of pro-inflammatory cytokines in rats with experimental periodontitis. J Periodontal Res 2009; 44: 133-40.

10. Holzhausen M, Garcia DF, Pepato MT, Marcantonio E Jr. The influence of short-term diabetes mellitus and insulin therapy on alveolar bone loss in rats. J Periodontal Res 2004; 39: 188-93.

11. Nassar CA, Nassar PO, Nassar PM, Spolidorio LC. Selective cyclooxygenase-2 inhibition prevents bone resorption. Braz Oral res 2005; 19: 36-40.

12. Azambuja CB, Cavagni J, Wagner MC, Gaio EJ, Rosing CK. Correlation analysis of alveolar bone loss in buccal/palatal and proximal surfaces in rats. Braz Oral Res 2012; 26: 571-7.

13. Li $\mathrm{CH}$, Amar S. Morphometric, histomorphometric, and microcomputed tomographic analysis of periodontal inflammatory lesions in a murine model. J Periodontol 2007; 78: 1120-8. 
14. Breivik T, Opstad PK, Gjermo P, Thrane PS. Effects of hypothalamic-pituitary-adrenal axis reactivity on periodontal tissue destruction in rats. Eur J Oral Sci 2000; 108: 115-22.

15. Liu YF, Wu LA, Wang J, Wen LY, Wang XJ. Micro-computerized tomography analysis of alveolar bone loss in ligature- and nicotine-induced experimental periodontitis in rats. J Periodontal Res 2010; 45: 714-9.

16. Niikura K, Takeshita N, Chida N. A novel inhibitor of vacuolar ATPase, FR202126, prevents alveolar bone destruction in experimental periodontitis in rats. The J Toxicologic Sci 2005; 30: 297-304.

17. Wu YH, Kuraji R, Taya $Y$, Ito $H$, Numabe $Y$. Effects of theaflavins on tissue inflammation and bone resorption on experimental periodontitis in rats. J Periodontal Res 2018; 53: 1009-19.

18. Wang X, Jia Z, Almoshari Y, Lele SM, Reinhardt RA, Wang D. Local Application of Pyrophosphorylated Simvastatin Prevents Experimental Periodontitis. Pharmaceutical Res 2018; 35: 164.

19. Toker H, Yuce HB, Yildirim A, Tekin MB, Gevrek F. The effect of colchicine on alveolar bone loss in ligature-induced periodontitis. Braz Oral Res 2019; 33: e001.

20. Bak EJ, Park HG, Kim M, Kim SW, Kim S, Choi S-H, et al. The effect of metformin on alveolar bone in ligature-induced periodontitis in rats: a pilot study. J Periodontol 2010; 81: 412-9.

21. Lee HJ, Lee DR, Choi BK, Yang SH. Antiperiodontitis effects of magnolia biondii extract on ligature-induced periodontitis in Rats. Nutrients 2019; 11: 934.

22. Taskan MM, Balci Yuce H, Karatas O, Gevrek F, Toker H. Evaluation of the effect of oleuropein on alveolar bone loss, inflammation, and apoptosis in experimental periodontitis. J Periodontal Res 2019; 54: 624-32.

23. Balci Yuce H, Toker H, Yildirim A, Tekin MB, Gevrek F, Altunbas $N$. The effect of luteolin in prevention of periodontal disease in Wistar rats. J Periodontol 2019; 90: 1481-9.

24. Alexandre JTM, Sousa LHT, Lisboa MRP, Furlaneto FAC, do Val DR, Marques $\mathrm{M}$, et al. Anti-inflammatory and antiresorptive effects of Calendula officinalis on inflammatory bone loss in rats. Clini Oral Investig 2018; 22: 2175-85.

25. Kuhr A, Popa-Wagner A, Schmoll H, Schwahn C, Kocher T. Observations on experimental marginal periodontitis in rats. $J$ Periodontal Res 2004; 39: 101-6.

26. Gaspersic R, Stiblar-Martincic D, Osredkar J, Skaleric U. Influence of subcutaneous administration of recombinant TNF-alpha on ligature-induced periodontitis in rats. J Periodontal Res 2003; 38: 198-203.

27. Nociti FH Jr., Nogueira-Filho GR, Primo MT, Machado MA, Tramontina VA, Barros SP, et al. The influence of nicotine on the bone loss rate in ligature-induced periodontitis. A histometric study in rats. J Periodontol 2000; 71: 1460-4.
28. Park CH, Abramson ZR, Taba M Jr, Jin Q, Chang J, Kreider JM, et al. Three-dimensional micro-computed tomographic imaging of alveolar bone in experimental bone loss or repair. J Periodontol 2007; 78: 273-81.

29. Correa MG, Absy S, Tenenbaum H, Ribeiro FV, Cirano FR, Casati $\mathrm{MZ}$, et al. Resveratrol attenuates oxidative stress during experimental periodontitis in rats exposed to cigarette smoke inhalation. J Periodontal Res 2019; 54: 225-32.

30. Cesar Neto JB, de Souza AP, Barbieri D, Moreno H Jr, Sallum EA, Nociti FH Jr. Matrix metalloproteinase-2 may be involved with increased bone loss associated with experimental periodontitis and smoking: a study in rats. J Periodontol 2004; 75: 995-1000.

31. Grauballe MC, Bentzen BH, Bjornsson M, Moe D, Jonassen TEN, Bendtzen $\mathrm{K}$, et al. The effect of spironolactone on experimental periodontitis in rats. J Periodontal Res 2005; 40: 212-7.

32. Verzeletti GN, Gaio EJ, Rosing CK. Effect of methotrexate on alveolar bone loss in experimental periodontitis in Wistar rats. Acta Odontol Scand 2007; 65: 348-51.

33. Ribeiro FV, Pino DS, Franck FC, Benatti BB, Tenenbaum H, Davies $\mathrm{JE}$, et al. Resveratrol Inhibits Periodontitis-Related Bone Loss in Rats Subjected to Cigarette Smoke Inhalation. J Periodontol 2017; 88: 788-98.

34. Yagan A, Kesim S, Liman N. Effect of low-dose doxycycline on serum oxidative status, gingival antioxidant levels, and alveolar bone loss in experimental periodontitis in rats. J Periodontol 2014; 85: 478-89.

35. Liberman DN, Pilau RM, Orlandini LF, Gaio EJ, Rosing CK. Comparison of two methods for alveolar bone loss measurement in an experimental periodontal disease model in rats. Braz Oral Res 2011; 25: 80-4.

36. de Souza DM, de Almeida Prado F, de Almeida Prado M, da Rocha RF, de Carvalho YR. Evaluation of two morphometric methods of bone loss percentages caused by periodontitis in rats in different locations. J Appl Oral Sci 2010; 18: 493-7.

37. Soletti AC, Gaio EJ, Rosing CK. Effect of neonatal clomipramine in the pathogenesis of ligature-induced periodontitis in Lewis rats. Acta Odontol Scand 2009; 67: 94-8.

38. Cavagni J, Soletti AC, Gaio EJ, Rosing CK. The effect of dexamethasone in the pathogenesis of ligature-induced periodontal disease in Wistar rats. Braz Oral Res 2005; 19: 290-4.

39. de Souza DM, Ricardo LH, Kantoski KZ, da Rocha RF. Influence of alcohol consumption on alveolar bone level associated with ligature-induced periodontitis in rats. Braz Oral Res 2009; 23: 326-32.

40. Bakır B, Ay ZY. Deneysel periodontitis çalışmalarında alveoler kemik kaybı ölçümlerinde direkt ve indirekt yöntemlerin karşılaştırılması. MAKÜ Sag Bil Enst Derg 2016; 4: 11-20. 